\title{
When Tenure Protects the Incompetent: Results from a Survey of Department Chairs
}

John M. Rothgeb, Jr., Miami University (Ohio)

ABSTRACT This research uses data from a national survey of political science department chairs to explore when tenure protects incompetent faculty. The characteristics of the responding institutions and the procedures and standards they use when evaluating tenure applications were analyzed to determine how they related to the protection of the incompetent. The results reveal that tenure is most likely to shield incompetent faculty when collegiality plays a role in tenure decisions and when departments focus on the quantity of articles an applicant publishes. The findings also show that when departments demand that candidates publish in prestigious journals and when higher authorities at the institution have reversed positive departmental tenure recommendations, the probability that the incompetent are protected declines.

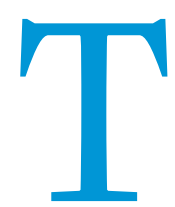

his research explores the circumstances under which tenure protects incompetent faculty. Incompetent faculty are those who fail to meet the teaching, research, and service expectations at their institution. Systematic research by Katz (1973), Kawar (1983), and Park and Riggs (1993) indicates that these were the criteria used for assessing faculty performance at every institution investigated, and an examination of American Association of University Professors (AAUP) documents reveals that these have been the accepted standards for evaluating faculty for nearly a century (AAUP 1915; 2009). ${ }^{2}$ As many readers know, the possible connection between tenure and incompetence is among the most contentious issues in higher education. Controversies associated with this subject have prompted many institutions to tighten the procedures and standards they use in making tenure decisions, to implement posttenure reviews, and to consider time limits on grants of tenure (see Goodman 1994; Kelley 2000; Turner 1997; Whicker 1997; Wood and Des Jarlais 2006). ${ }^{3}$

Although changing the system to try to prevent tenure from shielding nonperforming faculty could affect faculty careers and the freedom and creativity that are at the heart of academia, very little research has focused on the relationship between tenure and incompetence. Instead, the scholarly discussion of the problem has consisted of speculation regarding why some tenured faculty may not perform as expected. For example, in an early examina-

John M. Rothgeb, Jr. is professor of political science and distinguished scholar of the graduate school at Miami University in Oxford, Ohio. He is the author of numerous books and articles on international politics and foreign policy and on the discipline of political science. He can be reached at rothgejm@miamioh.edu. tion of the subject, Machlup $\left(1964,115^{-16}\right)$ argued that the explanation may reside in an improperly conducted tenure review process, the failure of institutional leaders to maintain a challenging academic environment, the personality traits of individual faculty, or characteristics specific to certain types of institutions. More recent discussions also point to these possibilities, with Lewis (1980, 87), Taylor (2010, 204-09), and Wood and Des Jarlais (2006, 563) describing faculty personalities and age as potential explanations; Whicker $(1997,22-23)$ asserting that institutional leadership plays a key role; and Brown and Kurland $(1990,331)$ and Pilant and Ellison $(1997,17)$ maintaining that tenure decision procedures and standards account for the problem.

The research to date has done little to clarify the matter, for it has dealt with such matters as how posttenure reviews are structured (Goodman 1994; Wood and Des Jarlais 2006); the use of external review letters in tenure cases (Schlozman 1998); whether the materials used in tenure reviews can predict successful academic careers (Lewis 1980); how well peer reviews, student evaluations, and portfolios measure teaching (Boyer 1990; Algozzine et al. 2004; Kelly-Woessner and Woessner 2006; Kohut, Burnap, and Yon 2007; Langbein 1994; Yon, Burnap, and Kohut 2002); the standards differing types of departments use in tenure decisions (Rothgeb and Burger 2009); and what variables are associated with the denial of tenure and with promotions in political science departments (Hesli, Lee, and Mitchell 2012; Marshall and Rothgeb 2011). This absence of research regarding when tenure protects the incompetent leaves a serious gap in our understanding of an important professional issue. It also prompts one to wonder how effective any tenure reforms can be if they are based more on conjecture than on empirical analysis. 
This essay addresses this need for research by systematically investigating how an institution's characteristics and the procedures and standards used to assess tenure applications are related to when tenure shields incompetent faculty. ${ }^{4}$ The following text describe how the data were obtained and analyzed.

\section{THE DATA}

This study uses data from a mail survey sent in February 2010 to 1,248 chairs of political science departments in the United States that offer bachelors, masters, and doctoral degrees. ${ }^{5}$ The APSA provided the names and addresses. ${ }^{6}$ Faulty addresses led to 36 returns for an effective population of 1,212. Responses were received from 361 chairs (58 doctoral departments, 77 offering a masters degree, and 226 with a bachelors program), yielding a response rate of $29.8 \%{ }^{7}$

Information for the dependent variable, tenure protects incompetent faculty, was acquired by asking the chairs to respond yes (coded 1) or no (coded o) to the following statement: "At my college/university, tenure has shielded incompetent faculty from dismissal." Among the respondents, $61.5 \%$ answered yes, while $38.5 \%$ said no. ${ }^{8}$ This procedure yielded a measurement indicating whether the problem of tenure protecting incompetence existed at the responding institution. As Euben (2002) illustrates, more detailed data pertaining to the magnitude of the incompetence problem from campus to campus requires the examination of data that often are afforded legal protection and/or that institutions hesitate to release. Acquiring such information, when it is available, probably is best pursued by means of campus-specific case studies. Still, the current measure should provide a useful starting point for the long-overdue analysis of an important tenurerelated issue. ${ }^{9}$ (yes $=1$, no $=0$ ), whether the department had set standards to guide tenure votes (yes $=1$, no $=0$ ), and whether a positive departmental tenure decision has been reversed by higher authorities (yes $=1$, no $=0$ ). The letters and standards variables were included to assess how much an institution attempted to reduce the roles of personality and institutional social connections in tenure decisions and to ensure that tenure candidates' records conform to discipline-wide views of excellence. The collegiality variable tends to tap the opposite impulse, reflecting the willingness to include in tenure decisions someone's ability to work as part of a professional team. Finally, reversal by higher authorities indicates how actively an institution's top administrators participate in tenure decision making. ${ }^{12}$

The standards variables pertained to research, teaching, and service. Six research variables were analyzed. Three related to publishing requirements to receive tenure: (1) the number of articles or the equivalent tenure candidates were expected to publish (no set requirement $=0$, one article $=1$, two or more $=2$, one per year $=3$, two or more per year $=4$ ), (2) the number of articles tenure candidates were expected to publish in the most prestigious journals in their specific field (no set requirement $=0$, one $=$ 1 , two or more $=2$, one per year $=3$, two or more per year $=4$ ), and (3) the number of books tenure candidates were expected to publish (no set requirement $=0$, one $=1$, two or more $=2$ ). In addition, chairs were asked whether single-authored publications were essential for tenure (yes $=1$, no $=0$ ), whether teaching publications were equal to substantive publications ( $y e s=1$, no $=0$ ), and whether research is the most important factor in the institution's tenure decisions (yes $=1$, no $=0$ ). ${ }^{13}$ Marshall and Rothgeb (2011, $576)$ and Rothgeb and Burger $(2009,517)$ used the first five of these variables to assess research requirements in tenure cases.

\section{The collegiality variable tends to tap the opposite impulse, reflecting the willingness to include in tenure decisions someone's ability to work as part of a professional team.}

The first of the independent variables pertained to institutional characteristics. These included total enrollment (coded 1 for fewer than 5,000 students, 2 for 5,000-10,000, 3 for 10,00120,000, and 4 for more than 20,000), location (rural $=1$, other $=$ o), whether the institution was public (coded 1) or private (coded o), and unionized (coded 1) or nonunionized (coded o). The public/ private and union/nonunion variables were included to assess assertions from the ongoing national debate regarding how these variables affect education. Privatization frequently is depicted as forcing institutions to use resources carefully because they receive less government support, making them more careful about granting tenure and less likely to have nonperforming tenured faculty on their staffs..$^{10}$ For their part, unions sometimes are described as protecting all employees regardless of performance, thus increasing the probability that unionized campuses will have incompetent tenured faculty members. ${ }^{11}$

As noted above, additional independent variables relating to the procedures and standards used during tenure reviews were analyzed. The procedural items comprised whether the chairs reported that collegiality is an important factor in tenure decisions at their college/university (coded yes $=1$, no $=0$ ), whether the institution required external review letters in tenure cases
The sixth variable was included to control for the emphasis placed on research in tenure decisions.

The teaching variables included several of the items Rothgeb and Burger $(2009,516)$ report are used to assess teaching during tenure reviews. These were (1) student evaluations (yes, teaching evaluations are required $=1$, no $=0$ ), (2) portfolios (yes $=1$, no $=0$ ), (3) peer reviews by a faculty member or administrator (yes $=1$, no $=0$ ), (4) whether tenure candidates are expected to create new courses (yes $=1$, no $=0$ ), and (5) whether the candidate teaches courses required by the department or the college/ university (yes $=1$, no $=0$ ). In addition, the chairs were asked to state whether teaching was the most important factor in tenure decisions at their institution (yes $=1$, no $=0$ ). Student evaluations, portfolios, and peer reviews tap the quality of an applicant's teaching, whereas teaching required courses and setting up new courses pertain to the candidate's curricular contributions. The teaching importance variable controlled for the emphasis placed on teaching during tenure reviews.

The last group of variables was for service. These included (1) whether tenure applicants were required to serve on at least one departmental committee (yes $=1$, no $=0$ ), (2) whether candidates were required to work with student clubs (yes $=1$, no $=0$ ), 
Table 1

Institutional Characteristics and Incompetence

\begin{tabular}{lcccc} 
INDEPENDENT VARIABLE & $\boldsymbol{B}$ & $\begin{array}{c}\text { STANDARD } \\
\text { ERROR }\end{array}$ & $\begin{array}{c}\text { WALD } \\
\text { CHANGE IN }\end{array}$ & $\begin{array}{c}\text { PROB. OF } \\
\text { INCOMPETENCE }\end{array}$ \\
\hline Public & .45 & .32 & 2.00 & - \\
\hline Union & .05 & .32 & .02 & - \\
\hline Enrollment & .02 & .15 & .03 & - \\
\hline Location & .03 & .26 & .01 & - \\
\hline Constant & .19 & .26 & .51 & - \\
\hline Cox and Snell $\mathrm{R}^{2}$ & .01 & & & \\
\hline Nagelkerke $\mathrm{R}^{2}$ & .02 & & & \\
\hline $\mathrm{N}$ & 329 & & & \\
\hline
\end{tabular}

Note: ${ }^{*} p<.05,{ }^{* *} p<.01,{ }^{* * *} p<.005$

(3) whether a strong commitment to advising was required (yes $=1, \mathrm{no}=0$ ), and (4) whether community service was expected (yes $=1$, no $=0){ }^{14}$

Logit regression analysis was used to assess how each cluster of independent variables affected incompetence. Logit is a regression technique that assesses how an independent variable affects a dichotomous dependent variable while controlling for the remaining variables in the analysis. ${ }^{15}$ The model used to examine the institutional variables provides an example of the basic equation:

Incompetence $=\mathrm{a}+\mathrm{b}_{1}$ Public $+\mathrm{b}_{2}$ Location $+\mathrm{b}_{3}$ Unionized

$$
+\mathrm{b}_{4} \text { Enrollment }+\mathrm{e}
$$

The same type of equation was used to evaluate each of the other variable clusters.

Before turning to the results, note that because colleges and universities have differing missions, a series of parallel analyses were conducted that controlled for such variables as the emphasis an institution places on research and teaching when making tenure decisions, whether attempts have been made to limit tenure at the institution, and the size of and the highest degree offered by the responding department. To save space, these additional results are not reported here, but in no case did these controls affect the results that are reported. ${ }^{16}$

\section{THE RESULTS}

Table 1 has the findings for institutional characteristics. As can be seen, none of the variables in this cluster affects the dependent variable, incompetence. ${ }^{17}$ This casts doubt on the claims some make regarding the effects of unionization and privatization on higher education.

The procedural results are in table 2. Two variables from this group affect incompetence, for collegiality is positively related, whereas reversal has a negative effect. ${ }^{18}$ Indeed, these findings suggest that when collegiality is an important consideration in a tenure case, the probability of incompetent faculty increases by .12, and that when higher authorities have reversed a positive department recommendation, the probability of incompetence decreases by .30. Neither of the remaining variables in this cluster affects incompetence, which is especially notable as far as outside
Table 2

\section{Tenure Evaluation Procedures and Incompetence}

\begin{tabular}{lcccc} 
INDEPENDENT VARIABLE & $\boldsymbol{B}$ & $\begin{array}{c}\text { STANDARD } \\
\text { ERROR }\end{array}$ & $\begin{array}{c}\text { WALD } \\
\text { Collegiality }\end{array}$ & $\begin{array}{c}\text { CHANGE IN } \\
\text { PROB. OF } \\
\text { INCOMPETENCE }\end{array}$ \\
\hline Letters & $.51^{*}$ & .24 & 4.44 & .12 \\
\hline Standards & .37 & .24 & 2.42 & - \\
\hline Reversed & -.30 & .35 & .72 & - \\
\hline Constant & $-1.25^{*}$ & .52 & 5.79 & -.30 \\
\hline Cox and Snell $\mathrm{R}^{2}$ & .30 & .38 & .62 & - \\
\hline Nagelkerke $\mathrm{R}^{2}$ & .04 & & & \\
\hline $\mathrm{N}$ & .05 & & & \\
\hline
\end{tabular}

Note: ${ }^{*} p<.05,{ }^{* *} p<.01,{ }^{* * *} p<.005$

Table 3

Research and Publishing and Incompetence

\begin{tabular}{|c|c|c|c|c|}
\hline INDEPENDENT VARIABLES & B & $\begin{array}{l}\text { STANDARD } \\
\text { ERROR }\end{array}$ & WALD & $\begin{array}{c}\text { CHANGE IN } \\
\text { PROB. OF } \\
\text { INCOMPETENCE }\end{array}$ \\
\hline \# Articles & $.35^{* * *}$ & .12 & 8.99 & .08 \\
\hline \# Books & -.43 & .30 & 2.10 & - \\
\hline \# Prestigious Articles & $-.66^{* * *}$ & .23 & 8.14 & -.16 \\
\hline Single Author & .39 & .26 & 2.28 & - \\
\hline Publications Equal & .25 & .25 & .94 & - \\
\hline $\begin{array}{l}\text { Research Most } \\
\text { Important }\end{array}$ & .53 & .33 & 2.67 & - \\
\hline Constant & .00 & .24 & .00 & - \\
\hline Cox and Snell $\mathrm{R}^{2}$ & .05 & & & \\
\hline Nagelkerke $\mathrm{R}^{2}$ & .07 & & & \\
\hline $\mathrm{N}$ & 325 & & & \\
\hline
\end{tabular}

letters are concerned because many institutions emphasize this evaluative device (see Schlozman 1998).

Table 3 has the research findings. Two variables stand out: the number of expected articles or chapters display a positive relationship, and the number of articles in prestigious journals reveal a negative association. The remaining variables were not related to incompetence. ${ }^{19}$ The positive relationship for the number of articles variable implies that a one-unit increase in the number of articles demanded from tenure candidates (that is, from one to two or more, or from two or more to one per year) increases the probability of incompetence by about .08, and the negative effect for the prestigious article variable suggests that a one-unit increase in the value of this variable decreases the probability of incompetence by .16. In other words, chairs from departments that focus on the quantity of publications appear more likely to report that tenure shields incompetence, whereas chairs of departments that emphasize quality journal articles have a greater tendency to state that tenure does not protect the incompetent. 
Table 4

\section{Teaching and Incompetence}

\begin{tabular}{lcccc} 
INDEPENDENT VARIABLE & $\boldsymbol{B}$ & $\begin{array}{c}\text { STANDARD } \\
\text { ERROR }\end{array}$ & WALD & $\begin{array}{c}\text { CHANGE IN } \\
\text { PROB. OF } \\
\text { INCOMPETENCE }\end{array}$ \\
\hline Student Evaluations & .34 & .51 & .45 & - \\
\hline Portfolios & .30 & .31 & .92 & - \\
\hline Peer Reviews & .04 & .30 & .02 & - \\
\hline Required Courses & .27 & .25 & 1.15 & - \\
\hline New Courses & -.22 & .26 & .73 & - \\
\hline Teaching Most & -.30 & .24 & 1.55 & - \\
Important & & & & - \\
\hline Constant & -.04 & .61 & .01 & - \\
\hline Cox and Snell $\mathrm{R}^{2}$ & .01 & & & \\
\hline Nagelkerke $\mathrm{R}^{2}$ & .02 & & & \\
\hline $\mathrm{N}$ & 328 & & & \\
\hline
\end{tabular}

Note: ${ }^{*} p<.05,{ }^{* *} p<.01,{ }^{* *} p<.005$

Table 5

Service and Incompetence

\begin{tabular}{lccrc} 
INDEPENDENT VARIABLE & $\boldsymbol{B}$ & $\begin{array}{c}\text { STANDARD } \\
\text { ERROR }\end{array}$ & WALD & $\begin{array}{c}\text { CHANGE IN } \\
\text { PROB. OF } \\
\text { INCOMPETENCE }\end{array}$ \\
\hline Committee Service & .17 & .26 & .40 & - \\
\hline Clubs & .51 & .45 & 1.32 & - \\
\hline Advising & -.17 & .29 & .34 & - \\
\hline Community Service & -.27 & .25 & 1.18 & - \\
\hline Constant & .52 & .32 & 2.68 & - \\
\hline Cox and Snell $\mathrm{R}^{2}$ & .01 & & & \\
\hline Nagelkerke $\mathrm{R}^{2}$ & .01 & & & \\
\hline $\mathrm{N}$ & 323 & & & \\
\hline
\end{tabular}

Note: ${ }^{*} p<.05,{ }^{* *} p<.01,{ }^{* * *} p<.005$

The results for teaching and service are shown in tables 4 and 5. As table 4 shows, neither the teaching quality nor the curricular contribution variables are related to incompetence. ${ }^{20}$ Table 5 reveals that the service variables also have no apparent association with incompetence. ${ }^{21}$

\section{DISCUSSION}

Before discussing conclusions, some caveats are in order. One is that the results here reflect relationships, not causal direction. For example, the absence of an association between outside letters and incompetence may be because some institutions adopt letters only after they recognize that they confront the problem of incompetence, while others adopt letters earlier. Another caveat pertains to the need for caution with the research results because in-depth evaluations of their application in differing teaching and research contexts are needed. ${ }^{22}$ One can, however, still glean useful insights from the current findings.

One insight comes from the institutional results indicating that the problem of tenure as a shield for the incompetent affects colleges and universities of all types. Whether large, medium, or small, unionized or nonunionized, rural or urban, or public or private, department chairs report that their colleges and universities confront problems stemming from tenure as a protector of the incompetent. These findings also show that much of the discussion in the media about the effects of unionization and privatization is misplaced, at least as far as higher education is concerned. ${ }^{23}$

A second insight is that some procedures do weed out the incompetent, whereas others do not. Reducing the role of collegiality in tenure decisions and demanding that higher level administrators carefully monitor tenure recommendations may help limit incompetence. Requiring evaluation letters from external reviewers and setting standards to guide tenure votes, however, appear less useful. Indeed, when one considers the many logistical and other problems Schlozman (1998) states accompany letters and the absence of an association between letters and the denial of tenure that Marshall and Rothgeb $(2011,574)$ report, one wonders whether this form of evaluation is worth the effort.

A third insight comes from the research results: quality matters. The findings herein suggest that colleges or universities that require candidates to publish in the top journals in their research field to receive tenure are less likely to regret tenure decisions over time. When the focus is on quantity, however, the chances seem to grow that future faculty performance may not match expectations. Juxtaposing this with Marshall and Rothgeb's (2011, 574) finding that the number of articles, not their location in prestigious journals, is a key variable in tenure decisions implies that departments and institutions that emphasize research and publishing when granting tenure may need to reconsider the way they evaluate applicants' records.

To close, this research is an initial exploration of a complex and controversial subject. To better understand the possible connection between tenure and incompetence, further inquiry is required. For instance, case studies and/or in-depth comparative analysis should seek the data needed to develop measures of the magnitude of the problem from campus to campus and to study the effects of such variables as personality, age, and institutional leadership. In addition, future analysis should examine the role of collegiality, how and why deans, provosts, and other officials and committees reverse positive departmental recommendations, how the quality and quantity of publications interact during tenure decisions, and how teaching and service expectations relate to the evaluation of faculty competence at differing institutions.

\section{NOTES}

1. In Beitzell v. Jeffrey (1981) the First Circuit Court of Appeals defined tenure as "a long-term academic and financial commitment by a university to an individual, providing faculty with unusually secure positions tantamount to life contracts" (see Mawdsley 1999, 167). In his widely quoted essay, Van Alstyne $(1971,329)$ observes that this security is because tenure establishes "a presumption of the individual's professional excellence ... [that] shifts to the individual the benefit of the doubt."

2. In its 1915 Declaration of Principles on Academic Freedom and Academic Tenure (AAUP 1915), the AAUP states that faculty duties include teaching, research, and governance (now labeled service). More recently, the AAUP's (2009) Recommended Institutional Regulations on Academic Freedom and Tenure (first issued in 1957) states that faculty fitness should be determined by their teaching, research, and service. These documents also recognize that the relative weight placed on teaching, research, and service may vary from campus to campus, depending upon the institution's mission. Beyond this, AAUP general counsel Donna Euben (2004) notes that in Browzin v. Catholic University of America (1975) the federal circuit court for the District of Columbia asserted that AAUP statements about academic practices "represent shared norms 
within the academic community" and "may be relied upon to interpret academic contracts." Additionally, Euben points out that in Korf v. Ball State University (1984) the Seventh Circuit Court of Appeals relied on AAUP regulations when reaching its decision and stated that the University's adherence to AAUP guidelines was legally sufficient. Finally, in King v. University of Min nesota (1985) the Eighth Circuit Court of Appeals upheld a tenured faculty member's dismissal for incompetence for failing to meet institutional teaching, research, and service expectations. Hence, one may conclude that defining incompetence as the failure to meet institutional teaching, research, and service obligations is the standard meaning used throughout the profession and that chairs and administrators would use this definition.

3. Incompetence is one reason for reform. Others include financial costs and programmatic inflexibility (see Dresch 1988; Kelley 2000; Whicker 1997). Euben $(2005)$ and Wood and Des Jarlais $(2006,561)$ note that 37 states required post-tenure reviews at public institutions by 2000 .

4. Institutional type and tenure review procedures and standards were explored because a survey approach is better suited to obtaining data for these variables than for personalities, age, and institutional leadership. These latter variables are better addressed by campus case studies and individual level analysis.

5. The Institutional Review Board for Human Subjects Research at Miami University (Ohio) approved this research.

6. The APSA list may not include some departments, thus introducing bias. Many previous professional surveys have used the APSA list (see Dolan et al 1997; Euchner and Jewell 1989, Fuerstman and Lavertu 2005, and Rothgeb and Burger 2009). Department chairs were surveyed because a pilot survey of the chief administrative officers (usually presidents or provosts) of the colleges/universities in the author's home state yielded a response rate of less than $5 \%$.

7. Due to anonymity, respondents and nonrespondents could not be compared.

8. Surveying chairs raises two issues: (1) are chairs aware of AAUP regulations regarding the use of teaching, research, and service to evaluate faculty performance and (2) can chairs provide an accurate picture of whether tenure shields the incompetent at their institution. Regarding the first issue, as noted above (see note \#2), AAUP guidelines treat teaching, research, and service as appropriate for evaluating faculty and federal courts have accepted those standards. In addition, the AAUP $(1989 ; 2009)$ states that chairs must ensure that faculty understand how they will be judged, and Hubbell and Homer $(1997,210)$, Knight and Holen $(1985,686)$, and Leslie $(1973,424)$ report that evaluating faculty is one of a chair's basic jobs and that teaching, research, and service are the standards employed. Therefore, one can assume that chairs use teaching, research, and service to define incompetence. Regarding the second issue, Hubbell and Homer $(1997,209)$ report that chairs are part of an institution's "management team," Leslie $(1973,423)$ and Wildavsky $(1992,87)$ note that chairs must understand all parts of their college/university, and Knight and Holen $(1985,677)$ assert that chairs do up to $80 \%$ of the administrative work in academia. Additionally, when higher administrators detect faculty incompetence they typically discuss the problem with chairs and expect chairs to handle the issue. Beyond this, the joint AAUP, American Council on Education, and Association of Governing Boards of Universities and Colleges Statement on Government of Colleges and Universities labels chairs "the chief representative of the department within an institution" (AAUP, 1990, 7). Hence, by virtue of their position chairs must understand other departments and administrative offices and their personnel. Moreover, when completing the current survey the responding chairs were instructed to "skip any items you cannot answer" and omit "any part of [the] survey [that] makes you uncomfortable or [that] you find inappropriate." Thus one may presume that chairs can report accurately on institutional incompetence and that those who felt unable to do so did not respond.

9. Although many discuss the subject, few have attempted to measure how often tenure protects incompetent faculty. As Brown and Kurland $(1990,332)$ have stated, "all the handwringing over deadwood [faculty] is remarkably devoid of anything resembling data." Wood and DesJarlais $(2006,562)$ note that little has changed, and Euben and Lee (2005) illustrate the dearth of data even on campuses with post-tenure review policies. Hence, while the current research employs a basic nominal measure, it constitutes a step forward. Additionally, as Kay $(1991,9)$ and Pampel $(2000,1)$ note, analyzing nominal data is useful for examining the relationships among variables.

10. Boyd (2007), Friedman (1962, 1995), Friedman and Friedman (1980), and Rhim (2007) discuss privatization in education. For-profit institutions were not analyzed. The AAUP $(2010,10)$ states that $17 \%$ of income at public colleges/universities and $29 \%$ at private institutions comes from tuition.

11. Friedman (1995) characterizes unions as shielding incompetence, however, there is little research on the subject. Research indicates that unions have a limited impact on salaries, but enhance job security (see Barbezat 1989; Benedict 1999; Benedict and Wilder 1999; Hedrick et al. 2011; Wickens 2008).

12. The survey obtained data regarding institutional budget cuts, the elimination or suspension of departments and programs, and faculty pay cuts and lay-offs. Additional analysis revealed no relationship between these variables and the reversal variable, indicating that they do not offer competing explanations for what is discussed herein.
13. Following the procedure employed by Rothgeb and Burger (2009, 519), chairs provided their own definitions for "teaching publications" and "substantive publications." Chairs also were told that a journal's prestige could be "determined by the evaluators at your institution." As endnote \# 2 indicates, it is common throughout the profession for institutions to determine how much they will stress quantity and quality when evaluating someone's publications. Boyer (1990, 39), Facione (2006), and Fisher et al. (1998) discuss teaching and substantive publications and collaborative scholarship.

14. The survey offered as examples school board service and government, business, or media consulting.

15. For discussions of logit, see Jaccard (2001), Menard (2002), and Pampel (2000).

16. The measures of additional control variables are available from the author.

17. These results were unaffected by controls for institutional attempts to limit tenure, institutional budget cuts, and the institution's emphasis on teaching and research.

18. These results were unaffected by controls for department size, whether the department had a tenure application, whether the department had denied someone tenure, departmental voting procedures, and whether probationary faculty received reduced teaching loads or paid leaves.

19. These results were unaffected by controls for department size, the highest degree offered by the department, and the institution's emphasis on teaching.

20. These findings were unaffected by controls for department size and the institution's emphasis on research.

21. These findings were unaffected by controls for department size and the institution's emphasis on teaching and research.

22. Among respondents, $42 \%$ said their institution treated teaching as most important in tenure cases, while $23 \%$ said it was research. The rest ranked teaching and research as equal.

23. Additionally, Marshall and Rothgeb $(2011,574)$ found that unionized facilities were more likely to deny tenure than non-unionized and that privatization was unrelated to denials of tenure.

\section{REFERENCES}

Algozzine, Bob, John Beattie, Marty Bray, Claudia Flowers, John Gretes, Lisa Howley, Ganesh Mohanty, and Fred Spooner. 2004. "Student Evaluation of College Teaching: A Practice in Search of Principles." College Teaching 52: 134-41.

American Association of University Professors (AAUP). 1915. 1915 Declaration of Principles on Academic Freedom and Academic Tenure. Available at www.aaup.org.

. 1989. Statement on Procedural Standards in the Renewal and Nonrenewal of Faculty Appointments. Available at www.aaup.org.

www.aaup.org.

. 2009. Recommended Institutional Regulations on Academic Freedom and Tenure. Available at www.aaup.org.

2010. No Refuge: The Annual Report on the Economic Status of the Profession, 2009-2010. Available at www.aaup.org.

Barbezat, Debra A. 1989. "The Effect of Collective Bargaining on Salaries in Higher Education." Industrial and Labor Relations Review 24 (April): 443-55.

Benedict, Mary Ellen. 1999. "The Union Effect on the Earning Distribution in Higher Education in Ohio." The American Economist 43 (Spring): 57-70.

Benedict, Mary Ellen, and Lisa Wilder. 1999. "Unionization and Tenure and Rank Outcomes in Ohio Universities." Journal of Labor Research XX (Spring): 185-201.

Boyd, William L. 2007. "The Politics of Privatization in American Education." Educational Policy 21 (1): 7-14.

Boyer, Ernest L. 199o. Scholarship Reconsidered: Priorities of the Professoriate. San Francisco: Jossey-Bass and the Carnegie Foundation for the Advancement of Teaching.

Brown, Ralph S., Jr., and Jordan E. Kurland. 1990. "Academic Tenure and Academic Freedom." Law and Contemporary Problems 53 (Summer): 325-55.

Dolan, Julie, Martha E. Kropf, Karen O'Connor, and Marni Ezra. 1997. “The Future of Our Discipline: The Status of Doctoral Students in Political Science." PS: Political Science and Politics 30 (4): 751-56.

Dresch, Stephen P. 1988. "Tenure and Faculty Quality in Post-Growth Academe." PS: Political Science and Politics 21 (1): 68-71.

Euben, Donna R. 2002. Tenure: Perspectives and Challenges. Available at www.aaup.org. 
2004. "Faculty Termination and Disciplinary Issues." Presented to 14 th Annual Legal Issues in Higher Education Conference at University of Vermont, October 24. Available at www.aaup.org.

2005. Post Tenure Review: Some Case Law. Available at www.aaup.org.

Euben, Donna R., and Barbara A. Lee. 2005. Managing Faculty Productivity after Tenure. Available at www.aaup.org.

Euchner, Jonathan P., and Malcolm E. Jewell. 1989. "A Survey of Teaching by Graduate Students." PS: Political Science and Politics 22 (1): 73-76.

Facione, Peter A. 2006. "Collaborative Scholarship and Tenure." Liberal Education 92 (Summer): $38-45$.

Fisher, Bonnie S., Craig T. Cobane, Thomas M. Vanderven, and Francis T. Cullen. 1998. "How Many Authors Does it Take to Publish an Article? Trends and Patterns in Political Science." PS: Political Science and Politics 31 (4): 847-56.

Friedman, Milton. 1962. Capitalism and Freedom. Chicago: University of Chicago Press.

_ 1995. "Public Schools Make Them Private." Briefing Paper No. 23. Washington, DC: CATO Institute.

Friedman, Milton, and Rose Friedman. 1980. Free to Choose: A Personal Statement. New York: Harcourt, Brace and Company.

Fuerstman, Daniel, and Stephan Lavertu. 2005. "The Academic Hiring Process: A Survey of Department Chairs." PS: Political Science and Politics 38 (4): 731-36.

Goodman, Madeleine J. 1994. "The Review of Tenured Faculty at a Research University: Outcomes and Appraisals." The Review of Higher Education 18 (Fall): 83-94.

Hedrick, David W., Steven E. Henson, John M. Krieg, and Charles S. Wassell, Jr. 2011. "Is There Really a Faculty Union Salary Premium?" Industrial and Labor Relations Review 64 (April): 558-75

Hesli, Vicki L., Jae Mook Lee, and Sara McLaughlin Mitchell. 2012. "Predicting Rank Attainment in Political Science: What Else Besides Publications Affects Promotion?" PS: Political Science and Politics 45 (3): 475-92.

Hubbell, Larry, and Fred Homer. 1997. "The Academic Department Chair: The Logic of Appeasement." PS: Political Science and Politics 30 (2): 209-13.

Jaccard, James. 2001. Interaction Effects in Logistic Regression. Thousand Oaks, CA: Sage Publications.

Katz, David A. 1973. "Faculty Salaries, Promotions, and Productivity at a Large University." American Economic Review 63 (June): 469-77.

Kawar, Amal. 1983. "Criteria for Tenure and Promotion at Public Universities and Colleges in the West.” PS: Political Science and Politics 16 (Summer): 541-43.

Kay, Susan Ann. 1991. Introduction to the Analysis of Political Data. Englewood Cliffs, NJ: Prentice-Hall, Inc.

Kelley, Michael A. 200o. "Political Science and Post-Tenure Review." PS: Political Science and Politics 33 (June): 233-36.

Kelly-Woessner, April, and Matthew Woessner. 2006. "My Professor is a Partisan Hack: How Perceptions of a Professor's Political Views Affect Student Course Evaluations." PS: Political Science And Politics 39 (3): 495-501.

Knight, W. Hal, and Michael C. Holen. 1985. "Leadership and the Perceived Effectiveness of Department Chairpersons." Journal of Higher Education 56 (November-December): 677-90.
Kohut, Gary F., Charles Burnap, and Maria G. Yon. 2007. "Peer Observation of Teaching: Perceptions Of the Observer and the Observed." College Teaching 55 19-25.

Langbein, Laura I. 1994. “The Validity of Student Evaluations of Teaching." PS: Political Science and Politics 27 (3): 545-53.

Leslie, David W. 1973. "The Status of the Department Chairmanship in University Organization.” AAUP Bulletin 59 (December): 419-26.

Lewis, Lionel S. 1980. "Academic Tenure: Its Recipients and Its Effects.” Annals of the American Academy of Political and Social Science 448 (March): 86-101.

Machlup, Fritz. 1964. "In Defense of Academic Tenure." AAUP Bulletin 5o (June): 112-24.

Marshall, Bryan W., and John M. Rothgeb, Jr. 2011. "So You Want Tenure? Factors Affecting Tenure Decisions In Political Science Departments." PS: Political Science and Politics 44 (3): 571-77.

Mawdsley, Ralph D. 1999. "Collegiality as a Factor in Tenure Decisions." Journal of Personnel Evaluation in Education 13: 167-77.

Menard, Scott. 2002. Applied Logistic Regression Analysis. Thousand Oaks, CA: Sage Publications.

Pampel, Fred C. 20oo. Logistic Regression: A Primer. Thousand Oaks: CA: Sage Publications.

Park, Betsy, and Robert Riggs. 1993. "Tenure and Promotion: A Study of Practices by Institutional Type." Journal of Academic Librarianship 19 (2): 72-77.

Pilant, Denny E., and Brian A. Ellison. 1997. “Two Perspectives on Tenure.” PS: Political Science and Politics 30 (1): 14-17.

Rhim, Lauren M. 2007. “The Politics of Privatization Practice.” Educational Policy 21 (1): 245-72.

Rothgeb, John M., Jr., and Betsy Burger. 2009. "Tenure Standards in Political Science Departments: Results from a Survey of Department Chairs." PS: Political Science and Politics 42 (3): 513-19.

Schlozman, Kay Lehman. 1998. "External Reviewers in Tenure and Promotion Decisions: How Does The Process Work? How Should It?" PS: Political Science and Politics 31 (3): 623-30.

Taylor, Mark C. 2010. Crisis on Campus: A Bold Plan for Reforming our Colleges and Universities. New York: Alfred A. Knopf.

Turner, Stephen. 1997. "Tenure and the Constitution of the University." PS: Political Science and Politics 30 (March): 17-20.

Van Alstyne, William. 1971. "Tenure: A Summary, Explanation, and 'Defense'." AAUP Bulletin 57 (Autumn): 328-33.

Whicker, Marcia Lynn. 1997. “An Economic Perspective on Academic Tenure.” PS Political Science And Politics 30 (1): 21-25

Wickens, Christine M. 2008. "The Organizational Impact of University Labor Unions.” Higher Education 56 (January): 545-64.

Wildavsky, Aaron. 1992. "On Being a Department Chair." PS: Political Science and Politics 25 (1): 83-89.

Wood, Melinda, and Chrstine Des Jarlais. 2006. "When Post-Tenure Review Policy and Practice Diverge: Making the Case for Congruence." The Journal of Higher Education 77 (July/August): 561-88.

Yon, Maria, Charles Burnap, and Gary Kohut. 2002. "Evidence of Effective Teaching: Perceptions of Peer Reviews." College Teaching 50: 104-10. 


\section{American Political Science Association}

\section{The APSA Distinguished Teaching Award}

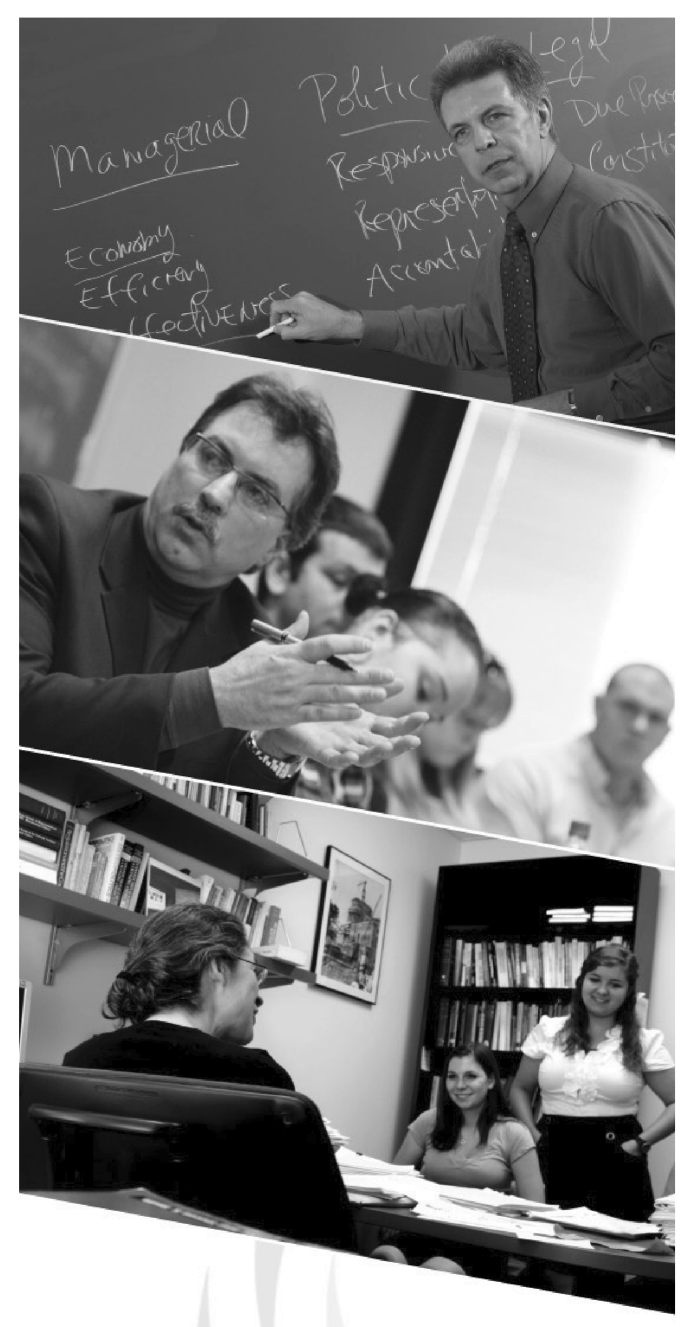

"By helping my students understand that group differences still matter in America, I am preparing them to live in our increasingly diverse society and forge solutions that will draw us closer together."

$$
\begin{aligned}
& \text { - Alvin Tillery } \\
& \text { Rutgers University }
\end{aligned}
$$

For more than 100 years, APSA has recognized excellence across the discipline. Its awards for scholarship and service are among the most distinguished in the discipline. The APSA Distinguished Teaching Award recognizes excellence in political science education.

The award honors the outstanding contributions of an individual to undergraduate and/or graduate teaching of political science at an institution of higher learning. It credits accomplishments aimed at enhancing teaching in the profession and it recognizes contributions spanning years or an entire career.

\section{Call for Nominations:}

The deadline for nominations is February 1, 2014. The award will be given during the 2014 Annual Meeting in Washington, DC. Nominations from departments, chairs, colleagues, and self-nominations are welcome.

\section{Learn more at www.apsanet.org/teachingaward}

For any questions or concerns regarding the award, please email APSATeachingAward@apsanet.org or call the APSA National Office at 202-483-2512

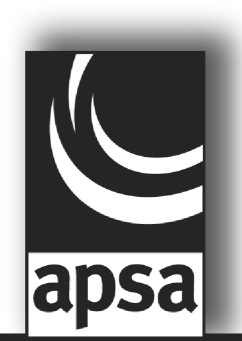

